\title{
MARTIAL POIRSON Les classiques ont-ils cru à leurs machines? La force du surnaturel dans La Devineresse ou les Faux enchantements (1679)
}

\section{Michel Lagier}

\section{OpenEdition}

\section{Édition électronique}

URL : http://journals.openedition.org/studifrancesi/33123

DOI : 10.4000/studifrancesi.33123

ISSN : 2421-5856

Éditeur

Rosenberg \& Sellier

\section{Édition imprimée}

Date de publication : 1 décembre 2005

Pagination : 635

ISSN : 0039-2944

\section{Référence électronique}

Michel Lagier, «MARTIAL POIRSON Les classiques ont-ils cru à leurs machines? La force du surnaturel dans La Devineresse ou les Faux enchantements (1679)", Studi Francesi [En ligne], 147 (XLX | III) | 2005, mis en ligne le 01 novembre 2015, consulté le 19 avril 2021. URL : http://journals.openedition.org/ studifrancesi/33123; DOI : https://doi.org/10.4000/studifrancesi.33123

Ce document a été généré automatiquement le 19 avril 2021

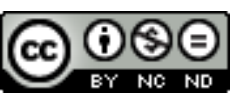

Studi Francesi è distribuita con Licenza Creative Commons Attribuzione - Non commerciale - Non opere derivate 4.0 Internazionale. 


\title{
MARTIAL POIRSON Les classiques ont-ils cru à leurs machines? La force du surnaturel dans La Devineresse ou les Faux enchantements (1679)
}

\author{
Michel Lagier
}

\section{RÉFÉRENCE}

MARTIAL POIRSON Les classiques ont-ils cru à leurs machines? La force du surnaturel dans La Devineresse ou les Faux enchantements (1679), «Revue d'histoire du théâtre», juilletseptembre 2004, pp. 181-194.

1 Pour M. Poirson, La Devineresse ou les Faux enchantements de Th. Corneille et Donneau de Visé apparaît comme l'apothéose du théâtre à machines en même temps qu'elle en dénonce le mode de fonctionnement reposant sur l'illusion. Se faisant l'écho de l'esprit libertin du XVII ${ }^{\mathrm{e}}$ siècle, annonçant l'esprit philosophique et critique du XVIII ${ }^{\mathrm{e}}$, utilisant l'actualité politique et sociale, et mélangeant les genres dans une production à grand spectacle, l'œuvre pose le problème du statut de l'artifice dans la comédie classique. En relation étroite avec l'actualité: l'affaire de la Voisin, la pièce s'inscrit dans la politique alors menée de répression contre la sorcellerie, ce qui n' en fait pas pour autant une œuvre de circonstance car cette chasse aux sorcières était déjà en déclin. Alors que les pièces à machines magnifient généralement le pouvoir monarchique, La Devineresse met en scène une affaire bien compromettante pour celui-ci mais en la démystifiant et en la dédramatisant, et sans proposer d'analyse politique, ce qui limite sa portée critique. Série de portraits plus qu'intrigue fortement nouée à la manière classique, l'oeuvre utilise de façon didactique l'artifice théâtral pour dénoncer l'artifice social. Mettant en place des enchaînements qui ont quelque chose de mécanique, la pièce est en effet construite sur une série de mises à l'épreuve des dons de la devineresse, l'obligeant à 
utiliser des machines pour créer l'illusion. Le théâtre met alors celle-ci à distance, ce qui témoigne d'un changement des mentalités et de l'essor des pratiques expérimentales. Ainsi La Devineresse apparaît comme l'une des manifestations d'un genre nouveau: la comédie de mœurs, qui se propose d'étudier le fonctionnement du jeu social et de ses pratiques trompeuses. C'est paradoxalement le genre utilisant le plus l'artifice, à savoir la pièce à machines, qui sert à dénoncer l'artifice théâtral. Finalement, conclut M. Poirson, peu importe de savoir si les classiques ont cru à leurs machines. Au théâtre ils en attendent la vraisemblance, la crédibilité et le divertissement. 